\title{
Soil disturbance and aspen regeneration on clay soils: Three case histories
}

\author{
by Douglas M. Stone ${ }^{1}$ and John D. Elioff
}

Sustaining forest productivity requires maintaining soil productivity and prompt establishment of adequate regeneration following harvest. We determined effects of commercial, winter-logging of aspen-dominated stands on soil disturbance and development of regeneration on three sites with clay soils. We established transects across each site, recorded pre-harvest stand information, post-harvest site disturbance, and first-year aspen sucker density and height. Use of large logging equipment produced heavy disturbance on $38 \%$ of a well-drained site; $45 \%$ of the area had no aspen suckers and $82 \%$ had less than the recommended minimum of $15000(15 \mathrm{k})$ suckers per ha $\left(6 \mathrm{k} \mathrm{ac}{ }^{-1}\right)$. Mean height of dominant suckers was $45 \mathrm{~cm}$ (18 in). Hand felling and a small skidder caused heavy disturbance on $12 \%$ of a moderately well-drained site. Sucker density averaged $34 \mathrm{k} \mathrm{ha}^{-1}\left(14 \mathrm{k} \mathrm{ac}^{-1}\right)$ and height was $97 \mathrm{~cm}$ (38 in). Cut-to-length (CTL) equipment produced heavy disturbance on $11 \%$ of a somewhat poorly-drained site, mean sucker density of $24 \mathrm{k} \mathrm{ha}^{-1}\left(9.6 \mathrm{k} \mathrm{ac}^{-1}\right)$, and height of $101 \mathrm{~cm}$ (40 in). These severely disturbed areas essentially are removed from the aspen-producing land base. Retaining the northern hardwood and conifer growing stock would result in less site disturbance and help maintain natural hydrologic and nutrient cycling processes.

Key words: aspen management, site disturbance, sustainable management, logging damage, soil rutting, root damage, evapotranspiration, soil aeration, clearcutting with residuals

La durabilité de la productivité forestière requiert le maintien de la productivité du sol et l'établissement rapide d'une régénération adéquate après la récolte. Nous avons déterminé les effets de la récolte commerciale effectuée au cours de l'hiver de peuplements à dominance de peuplier sur la perturbation du sol et le développement de la régénération sur trois stations composées de sol argileux. Nous avons effectué des relevés sur chacune des stations, afin de noter l'information sur le peuplement avant la récolte, la perturbation de la station après la récolte, et la densité et la hauteur des drageons de peuplier après un an de croissance. L'utilisation d'une machinerie lourde d'exploitation forestière a engendré une forte perturbation de $38 \%$ de la station à drainage rapide, $45 \%$ de la superficie ne comptait pas de drageon et $82 \%$ avait moins que le minimum recommandé de $15000(15 \mathrm{k})$ drageons par ha $\left(6 \mathrm{k} \mathrm{ac}^{-1}\right)$. La hauteur moyenne des drageons dominants était de $45 \mathrm{~cm}$ (18 po) L'abattage manuel et l'utilisation d'un petit débardeur ont engendré une forte perturbation sur $12 \%$ de la station à drainage relativement adéquat. La densité des drageons était en moyenne de $34 \mathrm{k} \mathrm{ha}^{-1}\left(14 \mathrm{k} \mathrm{ac}^{-1}\right)$ et la hauteur atteignait $97 \mathrm{~cm}$ (38 po). L'équipement de coupe en longueur a engendré une forte perturbation de $11 \%$ de la station relativement mal drainée, la densité moyenne des drageons était de $24 \mathrm{k} \mathrm{ha}^{-1}\left(9,6 \mathrm{k} \mathrm{ac}^{-1}\right)$, et la hauteur, de $101 \mathrm{~cm}(40 \mathrm{po})$. Ces sites très perturbés sont dans l'ensemble retirés du territoire productif du peuplier. Le maintien des stocks en croissance de feuillus nordiques et de conifères permettrait de moins perturber la station et aiderait au maintien des processus naturels d'hydrologie et du cycle des éléments nutritifs.

Mots-clés: aménagement du peuplier, perturbation de la station, aménagement durable, blessures d'exploitation, orniérage, blessures aux racines, évapotranspiration, aération du sol, coupe à blanc avec arbres résiduels

\section{Introduction}

Sustaining forest productivity from one rotation to the next requires: (1) maintaining soil productivity, and (2) prompt establishment of adequate regeneration. Forest harvesting is likely to have greater impacts on site productivity than any other activity during the rotation. Harvesting procedures that degrade soil properties and damage the parent root systems can impact the development of aspen suckers and thus, the density and species composition of the subsequent regeneration. As part of an international network of cooperative studies on long-term soil productivity (LTSP) (Powers et al. 1990, Tiarks et al. 1993), we are evaluating effects of soil compaction and organic matter removal in the aspen (Populus tremuloides Michx. and $P$. grandidentata Michx.) forest type across the northern Great Lakes region and in northeastern British Columbia (Kabzems 1996, Stone and Elioff 1998, Stone et al. 1999). To extend these experimental results to operational conditions, we are monitoring effects of commercial logging of aspen-dominated stands on site disturbance and on the composition and development of regeneration for several years following harvest. We report results from three sites on the Ontonagon Ranger District, Ottawa National

${ }^{1}$ USDA Forest Service, North Central Research Station, 1831 Highway 169 East, Grand Rapids, Minnesota 55744. E-mail: dstone01@fs.fed.us

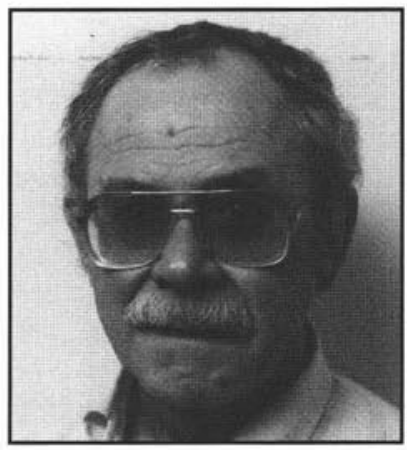

Douglas Stone

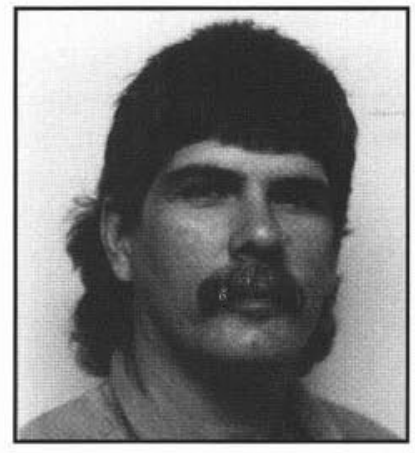

John Elioff
Forest in western Upper Michigan. Each site is dominated by calcareous clay soils (Table 1) and was commercially harvested during mid-winter by different loggers using different combinations of felling and skidding equipment.

\section{Methods}

\section{Stand and Site Conditions}

District personnel provided stand information and Landtype Phase (Avers et al.1994, Cleland et al. 1997) maps and site descriptions for several 60 - to 65 -year-old stands that were included 


\begin{tabular}{|c|c|c|c|c|c|c|c|}
\hline $\begin{array}{c}\text { Site } \\
\text { Name }\end{array}$ & $\begin{array}{c}\text { Stand } \\
\text { Area (ha) }\end{array}$ & $\begin{array}{c}\text { Landtype } \\
\text { Phase }^{\mathrm{a}}\end{array}$ & $\begin{array}{c}\text { Parent } \\
\text { Material }\end{array}$ & $\begin{array}{c}\text { Drainage } \\
\text { Class }^{\mathrm{b}}\end{array}$ & $\begin{array}{c}\text { Habitat } \\
\text { Type }^{c}\end{array}$ & $\begin{array}{c}\text { Forest } \\
\text { Type }\end{array}$ & $\begin{array}{c}\text { Est. Site } \\
\text { Index-m (ft) }\end{array}$ \\
\hline Marsh Grass & 10 & $226 \mathrm{~B}$ & Clay/Till ${ }^{\mathrm{d}}$ & Well & TAM & Aspen/NH ${ }^{\mathrm{e}}$ & $20(65)$ \\
\hline West Branch & 13 & $216 \mathrm{~B}$ & Clay & MW & TAM & Aspen/NH & $18(60)$ \\
\hline Beaver Pond & 14 & $217 \mathrm{~A}$ & Clay & SP & TTP & Aspen/BFf & $17(55)$ \\
\hline
\end{tabular}

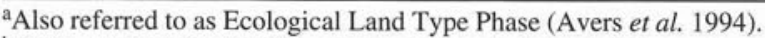

${ }^{b}$ Well - well-drained; MW - moderately well-drained; SP - somewhat poorly-drained.

'TAM - Tsuga-Acer-Mitchella; TTP - Tsuga-Thuja-Petastites; (Coffman et al. 1983, Kotar et al. 1988).

${ }^{\mathrm{d}}$ Lacustrine clay deposited over till.

'Predominantly black ash and basswood; sugar maple, red maple, yellow birch, and red oak also present.

${ }^{\mathrm{f}}$ Aspen, balsam fir, and white spruce.

Table 2. Pre-harvest merchantable basal area of aspen and associated species on the study sites

\begin{tabular}{llccc}
\hline & & \multicolumn{3}{c}{ Basal area } \\
\cline { 2 - 5 } Site & Species & $\left(\mathbf{m}^{\mathbf{2}} \mathbf{h a}^{-\mathbf{1}}\right)$ & $\left(\mathbf{f t}^{\mathbf{2}} \mathbf{a c}^{-\mathbf{1}}\right)$ & $\mathbf{( \% )}$ \\
\hline Marsh Grass & Aspen & 10.3 & 45 & 46 \\
& Northern hardwoods & 12.2 & 53 & 54 \\
& Total & 22.5 & 98 & \\
& & & & \\
West Branch & Aspen/paper birch & 13.8 & 60 & 52 \\
& Sugar maple/white spruce & 12.9 & 56 & 48 \\
& Total & 26.6 & 116 & \\
Beaver Pond & & 13.8 & 60 & 65 \\
& Aspen & 7.3 & 32 & 35 \\
& White spruce/balsam fir & 21.1 & 92 & \\
\hline & Total & & &
\end{tabular}

in conventional national forest timber sales but had not yet been harvested. The stands were typical of those throughout the northern Great Lakes region that developed following exploitative logging and extensive slash-fuelled wildfires (Stone and Strand 1997). We previously described four stands growing on soils similar to the LTSP installation and with a range of soil and site characteristics and stand conditions (Stone 1997). However, when logging of one of them (North Country) began, the equipment produced deep rutting and damage to the residual stand, so harvest operations were suspended. The remaining three sites provide a case history of conventional, winter harvesting of aspen-dominated stands on soils with a range of internal drainage (Table 1). Except for scattered minor depressions and drainages, the sites are nearly level $(<3 \%$ slope $)$. We used data from the LTSP plots and nearby stands (Alban et al. 1991) to estimate the 50-year site index for aspen. The Marsh Grass site is predominantly well-drained with an estimated site index of about $20 \mathrm{~m}$ ( $65 \mathrm{ft})$. Soils on the West Branch site are most similar to those of the LTSP installation, moderately well-drained, with a site index of about $18 \mathrm{~m}(60 \mathrm{ft})$. The Beaver Pond site is predominantly somewhat poorly-drained and contains poorly-drained inclusions; site index averaged about $17 \mathrm{~m}(55 \mathrm{ft})$.

The overstorey of each stand was dominated by aspen but included a codominant component, or a subcanopy of northern hardwood species, white spruce (Picea glauca (Moench) Voss), and balsam fir (Abies balsamea (L.) Mill.) (Table 2). The Marsh Grass stand had a merchantable basal area of $22.5 \mathrm{~m}^{2}$ $\mathrm{ha}^{-1}\left(98 \mathrm{ft}^{2} \mathrm{ac}^{-1}\right) ; 46 \%$ was aspen. The balance was predominantly black ash (Fraxinus nigra Marsh.) and basswood (Tilia americana L.); sugar maple (Acer saccharum Marsh.), red maple (Acer rubrum L.), yellow birch (Betula alleghanien- sis Britt.), northern red oak (Quercus rubra L.), and balsam fir also were present. Aspen and paper birch (Betula. papyrifera Marsh.) were the predominant species in the West Branch stand and made up $52 \%$ of the basal area. Sugar and red maple, white spruce, red oak, white pine (Pinus strobus L.), and balsam fir comprised the remainder. The Beaver Pond stand was classified as over-mature aspen/balsam fir; however, much of the balsam had been wind-thrown one to three years before the study was started, leaving a predominantly aspen overstorey comprising $65 \%$ of the $21.1 \mathrm{~m}^{2} \mathrm{ha}^{-1}\left(92 \mathrm{ft}^{2} \mathrm{ac}^{-1}\right)$ of total basal area. The balance included white spruce, balsam fir, sugar and red maple, basswood, black ash, paper birch, and northern whitecedar (Thuja occidentalis L.).

\section{Sampling and Measurements}

Prior to harvest, we established transects about $30 \mathrm{~m}$ (1.5 chains) apart across each stand and marked sample points every $5 \mathrm{~m}$ ( 0.25 chain) to assess site disturbance and to monitor development of regeneration (Table 3). Every $25 \mathrm{~m}$ along each line, we measured the basal area of all live trees $\geq 10 \mathrm{~cm}$ ( 4 in) dbh, recorded the basal area of aspen, total basal area of all species, and the predominant overstorey species. Mean basal area of aspen, total basal area, and predominant overstorey species were summarized for each stand.

The Marsh Grass stand was harvested during late December, 1995 and early January, 1996. Snow depths ranged from 90 to $100 \mathrm{~cm}$ ( 36 to $40 \mathrm{in}$ ) and the soils were not frozen. The logging equipment included a Hydro-Ax model 311 feller-buncher, a Caterpillar 518 grapple skidder, and a slasher-loader set up at a roadside landing. The trees were limbed and topped on site and skidded tree-length to the landing. The West Branch stand was harvested during the same period by chainsaw felling and limbing and tree-length skidding with a John Deere 440 cable skidder to a temporary road constructed through the central portion of the stand. A John Deere 550 crawler tractor was used to plow snow from the skid trails. The Beaver Pond stand was harvested during January and February, 1997 with a six-wheel drive Timberjack $1270 \mathrm{~B}$ cut-to-length harvester and a six-wheel drive Timberjack 1010B forwarder. Snow depths ranged from 76 to $90 \mathrm{~cm}$ (30 to 36 in) and the soils were not frozen. After logging was completed on each site, all residual hardwood stems $>5 \mathrm{~cm}$ ( 2 in) dbh were cut with chainsaws, a standard practice on this District.

During the first spring following logging we visually classified soil disturbance on a circular, $5-\mathrm{m}^{2}$ plot at each sample point on each site using the following classes: (1) litter layer intact; (2) litter removed; (3) litter-soil mixed; (4) surface soil moved; (5) machine track; (6) rut $<10 \mathrm{~cm}$ deep; (7) rut $10 \mathrm{~cm}$ 
Table 3. Distribution of general disturbance classes on three sites harvested with different equipment

\begin{tabular}{|c|c|c|c|c|c|}
\hline \multirow[b]{2}{*}{ Site } & \multirow{2}{*}{$\begin{array}{l}\text { Sample } \\
\text { Plots (n) }\end{array}$} & None & Light & Heavy & Slash \\
\hline & & \multicolumn{4}{|c|}{ Percent of sample area } \\
\hline Marsh Grass ${ }^{a}$ & 345 & 43 & 13 & 38 & 6 \\
\hline West Branch ${ }^{b}$ & 550 & 67 & 5 & 12 & 16 \\
\hline Beaver Pond ${ }^{c}$ & 690 & 49 & 22 & 11 & 18 \\
\hline
\end{tabular}

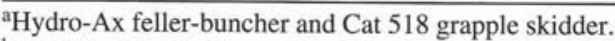

bJD 440 cable skidder and JD 550 crawler tractor snowplow.

'Timberjack six-wheel-drive CTL processor and forwarder.

\begin{tabular}{|c|c|c|c|c|}
\hline \multicolumn{2}{|c|}{ Sucker density } & \multirow[b]{2}{*}{ Marsh Grass $^{a}$} & \multirow[b]{2}{*}{ West Branch } & \multirow[b]{2}{*}{ Beaver Pond } \\
\hline$\left(\mathrm{k} \mathrm{ha}^{-1}\right)$ & $\left(\mathrm{k} \mathrm{ac}^{-1}\right)$ & & & \\
\hline None & None & 44.9 & 8.2 & 17.4 \\
\hline $0.1-14.9$ & $0.1-5.9$ & 37.4 & 23.3 & 26.8 \\
\hline $15.0-29.9$ & $6.0-11.9$ & 7.6 & 23.2 & 22.6 \\
\hline $30.0-44.9$ & $12.0-17.9$ & 4.1 & 19.9 & 16.4 \\
\hline $45.0-59.9$ & $18.0-23.9$ & 2.9 & 10.0 & 9.4 \\
\hline $60.0-74.9$ & $24.0-29.9$ & 2.0 & 5.6 & 4.4 \\
\hline $75.0-89.9$ & $30.0-35.9$ & 0.3 & 3.5 & 1.4 \\
\hline $90.0+$ & $36.0+$ & 0.6 & 6.5 & 1.6 \\
\hline
\end{tabular}

${ }^{\text {aSee footnotes, Table } 3 .}$

to $20 \mathrm{~cm}$; (8) rut $>20 \mathrm{~cm}$; (9) road, trail, or landing; (10) slash $>1 \mathrm{~m}$ deep or logs $\geq 50 \mathrm{~cm}$ deep; or (11) non-soil (predominantly stumps). When a plot included more than one class of disturbance, we estimated the area occupied by each class to the nearest 10 percent. The disturbance data were then consolidated into four general classes: "none" (1); "light" (2 to 5); "heavy" (6 to 9); or "non-soil" (slash and stumps). This grouping scheme was based on previous observations of soil disturbance and aspen regeneration on numerous additional recently harvested sites. We estimated the area of the site in each disturbance class based on the plot totals and calculated a weighted disturbance index for each plot by assigning a numeric value of 1,2 , or 3 to each general disturbance class and multiplying by the proportion of the area occupied by each. For example, if $60 \%$ of a plot was classified as "none," $30 \%$ as "light," and $10 \%$ "heavy," the weighted index was $(1 \times 6)+(2 \times 3)+(3 \times 1)$ $=15$. Thus, if all 10 segments of a plot were classified as "none," the disturbance index was 10 , or if all 10 were classified as "heavy," the index was 30 .

In September, after the first growing season, the number of aspen suckers on each 5- $\mathrm{m}^{2}$ plot and the height of the dominant sucker were recorded. The percentage of plots stocked and mean density of suckers were calculated for each stand. Relations between dominant sucker height and the weighted disturbance index were evaluated by linear regression (Analytical Software 1998).

\section{Results}

The combination of equipment size and operator skill and/or sensitivity to soil disturbance resulted in large differences in amount of area impacted by logging. The large equipment used on the Marsh Grass site produced visible soil disturbance on $51 \%$ of the sample area, of which $38 \%$ was heavy disturbance (Table 3). Chainsaw felling and the small skidder resulted in visible disturbance on $17 \%$ of the West Branch site, the least of the three logging jobs. The cut-to-length equipment pro- duced visible soil disturbance on $33 \%$ of the Beaver Pond site with $11 \%$ heavily disturbed, the least heavy disturbance of the three operations.

Winter harvesting of these aspen-dominated stands resulted in large differences in first-year regeneration of aspen suckers among the three sites. Most striking was the difference in the number of plots with no suckers, nearly $45 \%$ on the heavily disturbed Marsh Grass site compared to $8 \%$ and $17 \%$ on the less disturbed West Branch and Beaver Pond sites (Table 4). Likewise, more than $37 \%$ of the Marsh Grass site had less than 15000 suckers per ha $\left(6 \mathrm{k} \mathrm{ac}^{-1}\right)$ compared to about $25 \%$ on the other two sites. Mean density of aspen on the Marsh Grass site was 9000 suckers per ha $\left(3.6 \mathrm{k} \mathrm{ac}^{-1}\right)$, approximately one-fourth to one-third that on the other two sites (Table 5). Moreover, mean height of the suckers was less than half that of the other two sites. The linear regression between sucker height and the weighted disturbance index was highly significant, $\left(p<0.001, \mathrm{r}^{2}=0.10\right)$ for the Marsh Grass site (Fig. 1) but not for the other two.

\section{Discussion \\ Site Disturbance}

Both the area affected and degree of site disturbance during harvesting can vary greatly depending on soil conditions, type and size of equipment, and operator practices. In Lake States clearcuts, estimates of 50 to $95 \%$ of the area disturbed are common (Grigal and Bates 1992). Our estimates of the area that was disturbed probably are conservative for two reasons. First, machine traffic in deep snow can compact soil without leaving tracks (unpublished data on file), and secondly, ground vegetation and logging slash can conceal disturbance that is present. This underestimate is greatest on the Marsh Grass site where the fellerbuncher had to approach every tree that was cut. The data are more representative of actual conditions on the other two sites. On the Beaver Pond site, the boom of the harvester reached 5-6 m (16-20 ft) each side of the traffic corridor and the operator used the "walk-on-slash" technique. On the West 


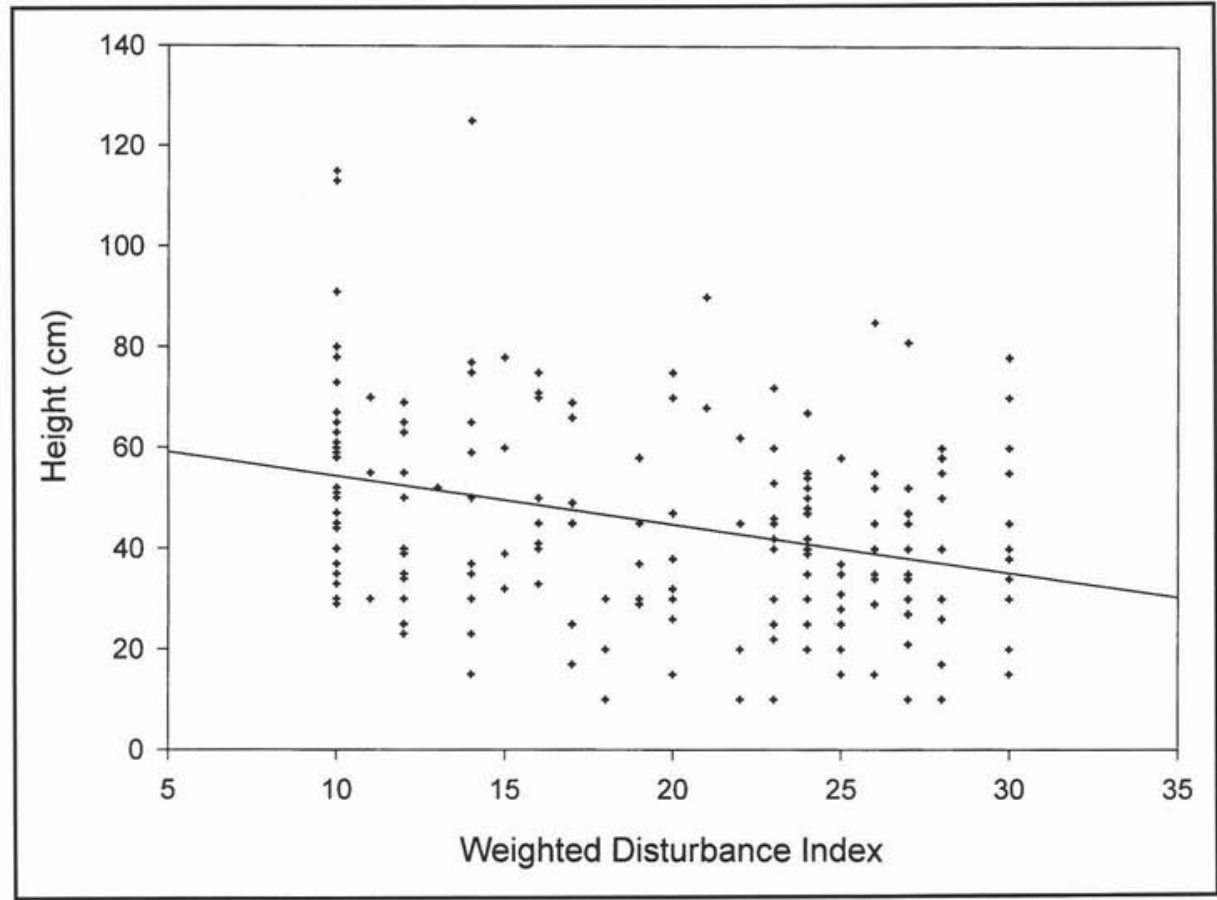

Fig. 1. Mean height of dominant aspen suckers related to weighted soil disturbance index - Marsh Grass site. Height $=63.8-0.95 \times$ Disturbance Index; $\left(p<0.001, \mathrm{r}^{2}=0.10\right)$.
Table 5. Proportion of area stocked, mean sucker density, and mean height of dominant suckers

\begin{tabular}{lccr}
\hline Site & $\begin{array}{c}\text { Stocked } \\
(\%)\end{array}$ & $\begin{array}{c}\text { Density } \\
\left(\mathbf{k ~ h a}^{-\mathbf{1}}\right)\end{array}$ & $\begin{array}{r}\text { Height } \\
(\mathbf{c m})\end{array}$ \\
\hline Marsh Grass & 55 & 9 & 45 \\
West Branch & 92 & 34.5 & 97 \\
Beaver Pond & 83 & 23.8 & 101 \\
\hline
\end{tabular}

Branch site, where the trees were felled and limbed with chainsaws, the operator restricted the skidder to the plowed trails, parked it at a location near several stems, attached a choker to each, and winched them to the skidder, thus minimizing the area trafficked by the skidder.

Lateral movement of water is critical to maintaining productivity of level sites with fine textured soils. Rutting and puddling disrupts the hydrologic integrity of these soils, decreases site productivity, and the effects are likely to persist for decades (Grigal 2000). Internal soil drainage was classified as well-drained on the Marsh Grass site, moderately well-drained on the West Branch, and somewhat poorly-drained on the Beaver Pond (Table 1). Prior to logging, we expected that the amount and severity of site disturbance also would be in that order and planned our sampling intensity accordingly (Table 3 ). Ironically, the greatest amount of severe disturbance, primarily due to rutting and puddling, occurred on the well-drained and most productive Marsh Grass site with the least disturbance on the somewhat poorly-drained and less productive Beaver Pond site (Table 3). Thus, on these sites, type and size of equipment and operator practices were more important in creating heavy site disturbance than were the inherent soil properties.

\section{Aspen Regeneration}

Probable reasons for the differences in aspen regeneration differ for each stand. The $45 \%$ of the Marsh Grass site lacking aspen suckers (Table 4) can be explained by the heavy site disturbance on $38 \%$ of the area (Table 3), and by the $54 \%$ of initial basal area comprised of associated species (Table 2) that tended to be aggregated in patches. Damaged root systems and disrupted internal soil drainage resulted in ponding of surface water and saturated soils well into the growing season. Clearcutting eliminated the major source of evapotranspiration and prolonged the duration of inadequate soil aeration. This combination of conditions severely reduced the density and first-year growth of aspen suckers. The $8 \%$ of the West Branch site with no suckers is due mainly to the temporary road through the site, to concentrations of short logs along the road, and occasionally to deep slash where the tops of two or more trees were felled upon each other. Although the maple and other associated species made up $48 \%$ of the merchantable basal area, they tended to be distributed throughout the stand rather than in groups or patches, so probably had minimal effects on aspen root distribution. Most of the $17 \%$ of the Beaver Pond site without aspen stocking is due to sample points located in or near the poorly drained depressions initially occupied by sedges, alder, black ash, and red maple with few, if any, aspen roots present to produce suckers.

The detrimental effects of heavy disturbance, primarily rutting (Table 3), also are illustrated by the differences in areas with less than 15000 suckers per ha $\left(6 \mathrm{k} \mathrm{ac}^{-1}\right)$, averaging 25\% on the West Branch and Beaver Pond sites and 37\% on the Marsh Grass site (Table 4). The mean values for percent stocking (Table 5) are optimistic for two reasons. First, if a single sucker was present on any $5-\mathrm{m}^{2}$ plot $\left(2 \mathrm{k} \mathrm{ha}^{-1}\right)$, it was considered "stocked." Secondly, most suckers develop the first growing season following winter harvest and stand density gradually declines in succeeding years (Perala 1984, Peterson and Peterson 1992 [Table 6]). Thus, the area presently considered as stocked is more likely to decline than to increase in the future.

The sucker density values (Table 5) are the means over each entire site. Graham et al. (1963) considered a mean sucker density of $15 \mathrm{k} \mathrm{ha}^{-1}\left(6 \mathrm{k} \mathrm{ac}^{-1}\right)$ as minimum and $30 \mathrm{k} \mathrm{ha}^{-1}\left(12 \mathrm{k} \mathrm{ac}^{-1}\right)$ 
as optimal. Using these standards, $82 \%$ of the Marsh Grass site is either non-stocked, or sucker density is inadequate, and mean sucker density is adequate on the West Branch site. Excluding the poorly-drained areas on the Beaver Pond site would increase mean sucker density to near $30 \mathrm{k} \mathrm{ha}^{-1}$. Aspen productivity on the Marsh Grass site was reduced additionally by the decreased height growth of the suckers (Table 5) which in turn, was significantly related to the weighted disturbance index (Fig. 1). The variation in these data is large and the regression explains a relatively small proportion of the total $\left(r^{2}=0.10\right)$ for several reasons. First, the height data represent the largest sucker on each plot rather than the population mean; secondly, because most of the plots included more than one disturbance class; and additionally, due to variation in variables that were not measured, including root damage, soil temperature and aeration, and clonal variation in sucker initiation. However, the data clearly illustrate a trend of decreasing sucker height with increasing site disturbance.

\section{Management Implications}

Early results from these case histories illustrate several points applicable to management of fine-textured soils in the northern Great Lakes region: (1) When soils are not frozen, deep snow cover provides little, if any, protection against soil compaction and rutting. This was illustrated by an average $10 \%$ increase in soil bulk density in the nearby LTSP installation (unpublished data on file) and by the visible soil disturbance on these sites (Table 3). These heavily disturbed areas - roads, trails, landings, and compacted and/or rutted areas - essentially are removed from the aspen-producing land base. (2) Contrary to popular belief, clearcutting of aspen-dominated stands does not always assure prompt and adequate regeneration (Navratil 1991). Inadequate sucker density is most common on level sites with fine-textured soils; these are likely to remain cold, wet, and oxygen-deficient well into the growing season (Bates et al. 1990, 1993). Moreover, few if any, aspen roots are likely to be present on those portions of a site occupied by associated species, particularly when they occur in groups or patches. (3) Managers should specify the type, size, and timing of harvest equipment used, based on ecological classification units and site conditions at the time of harvest. Use of large, heavy equipment should be avoided when soils are excessively moist, and soil strength is low. (4) In stands with a substantial component of associated species, managers should consider reserving the immature conifer and hardwood growing stock (Navratil et al. 1994). This could provide both soil management and silvicultural advantages. Removing only the aspen and mature conifers and hardwoods would require less machine traffic, and consequently, result in less site disturbance. The remaining partial canopy and advance regeneration would maintain a portion of the normal evapotranspiration and nutrient cycling processes resulting in less disruption of ecosystem functions. Provided the root systems are not damaged by severe soil disturbance, aspen suckers will be free to develop on those portions of the site initially occupied by aspen. Suckers are not needed on those portions of the site occupied by the associated species.

\section{Further research}

The extent of soil disturbance measured on the Marsh Grass site was due to a combination of circumstances and greatly exceed- ed the amount that is normally encountered or tolerated by the Ottawa National Forest. Additional research will attempt to quantify relations between soil water content, soil strength, static ground pressure of logging equipment, and their effects on soil disturbance, in order to develop predictive parameters and mitigation measures.

\section{Acknowledgements}

We thank David H. Alban (retired) and Donald A. Perala (retired), North Central Research Station; James K. Jordan (retired), Ottawa National Forest; Donald H. Prettyman (retired), Superior National Forest; Elon S. Verry, and John C. Zasada, North Central Research Station; and two anonymous reviewers for helpful comments and suggestions on a previous version of the manuscript. This work was supported in part by the Ottawa National Forest and the North Central Forest Experiment Station, Research Challenge Cost-Share Program.

\section{References}

Alban, D.H., D.A. Perala, M.F. Jurgensen, M.E Ostry and J.R Probst. 1991. Aspen ecosystem properties in the Upper Great Lakes. USDA For. Serv., North Central For. Exp. Stn. Res. Pap. NC-300. 47 p. Analytical Software. 1998. Statistix ${ }^{\circledR}$ for Windows. User's Manual. Tallahassee, FL. 333 p.

Avers, P.E., D.T. Cleland and W.H. McNab. 1994. National hierarchical framework of ecological units. In L.H. Foley (comp.). Silviculture: From the Cradle of Forestry to Ecosystem Management. Proc. National Silviculture Workshop. 1-4 November 1993, Hendersonville, NC. pp. 48-61. USDA For. Serv., Southeast. For. Exp. Stn., Gen. Tech. Rep. SE-88. 258 p.

Bates, P.C., C.R. Blinn and A.A. Alm. 1990. A survey of the harvesting histories of some poorly regenerated aspen stands in northern Minnesota. In R.D. Adams (ed.). Aspen Symposium '89, Proc. 25-27 July 1989, Duluth, MN. pp. 221-230. USDA For. Serv., North Central For. Exp. Stn., Gen Tech. Rep. NC-140. 348 p.

Bates, P.C., C.R. Blinn, A.A. Alm. 1993. Harvesting impacts on quaking aspen regeneration in northern Minnesota. Can. J. For. Res. 23: 2403-2412.

Cleland, D.T., P.E. Avers, W.H. McNab, M.E. Jensen, R.E. Bailey, T. King and W.E. Russell. 1997. National Hierarchical Framework of Ecological Units. In M.S. Boyce and A. Harvey (eds.). Ecosystem Management: Applications for Sustainable Forest and Wildlife Resources. pp. 181-200. Yale University Press. New Haven, CT.

Coffman, M.S., E. Alyanak, J. Kotar and J.E. Ferris. 1983. Field guide to habitat-type classification system for Upper Peninsula of Michigan and northeast Wisconsin. Dept. Forestry, Mich. Tech. Univ., Houghton, MI. 160 p.

Graham, S.A., R.P Harrison, Jr. and C.E. Westell, Jr. 1963. Aspens: Phoenix Trees of the Great Lakes Region. The Univ. Mich. Press. Ann Arbor, MI. 272 p.

Grigal, D.F. 2000. Effects of extensive forest management on soil productivity. For. Ecol. Manage. (In press).

Grigal, D.F. and P.C. Bates. 1992. Forest Soils. A technical paper for a generic environmental impact statement on timber harvesting and forest management in Minnesota. Jaakko Pöyry Consulting, Inc. Tarrytown, NY. 155 p.

Kabzems, R. 1996. Boreal long-term soil productivity study. Forest Research Note \#PG-06. BC Ministry of Forests, Prince George Forest Region, Prince George, BC. 4 p.

Kotar, J., J.A. Kovach and C.T. Locey. 1988. Field guide to forest habitat types of northern Wisconsin. Dept. Forestry, Univ. Wisc. and Wisc. Dept. Natural Resources. Madison, WI. 217 p.

Navratil, S. 1991. Regeneration challenges. In S. Navratil and P.B. Chapman (eds.). Aspen management for the $21^{\text {st }}$ century. Proc. 
Symp., 20-21 November 1990, Edmonton AB. pp. 15-27. For. Can., Northwest Reg., North. For. Cent. and Poplar Counc. Can., Edmonton, AB. 172 p.

Navratil, S., L.G. Brace, E.A. Sauder and S. Lux. 1994. Silvicultural and harvesting options to favor immature white spruce and aspen regeneration in boreal mixedwoods. Can. For. Serv., Northern For. Cent., Edmonton, AB. Inf. Rep. NOR-X-337. 74 p. + appendices.

Perala, D.A. 1984. How endemic injuries affect early growth of aspen suckers. Can. J. For. Res. 14: 755-762.

Peterson, E.B. and N.M. Peterson. 1992. Ecology, management, and use of aspen and balsam poplar in the prairie provinces. For. Can. Northwest Region, North. For. Cent. Edmonton, AB. Special Rep. \#1. 252 p. Powers, R.F., D.H. Alban, R.E. Miller, A.E. Tiarks, C.G. Wells, P.E. Avers, R.G. Cline, R.O. Fitzgerald and N.S Loftus, Jr. 1990. Sustaining site productivity in North American forests: problems and prospects. In S.P. Gessel, D.S. Lacate, G.F. Weetman and R.F. Powers (eds.) Sustained productivity of forest soils. Proc. 7th North Amer. For. Soils Conf., 23-29 July 1988, Vancouver, BC. pp. 49-79. University of British Columbia, Faculty of Forestry Publication. $525 \mathrm{p}$.

Stone, D.M. 1997. A decision tree to evaluate silvicultural alternatives for mature aspen in the northern Lake States. North. J. Appl. For. 14(2): 95-98.
Stone, D.M. and J.C. Strand. 1997. Monitoring the Mighty Duck Timber Sale: a National Forest - Conservation Organization Research Partnership. In Communicating the Role of Silviculture in Managing the National Forests: Proc. National Silviculture Workshop, 19-22 May 1997, Warren, PA. pp. 186B189. USDA For. Serv., Northeastern For. Exp. Stn., Gen. Tech. Rep. NE-238. 205 p.

Stone, D.M. and J.D. Elioff. 1998. Soil properties and aspen development five years after compaction and forest floor removal. Can. J. Soil Sci. 78: 51-58.

Stone, D.M., J.A. Gates and J.D. Elioff. 1999. Are we maintaining aspen productivity on sand soils? In B. ZumBahlen and A.R. Ek (comps.). Improving Forest Productivity For Timber - A Key to Sustainability. Proc. Conf. 1-3 December 1998, Duluth, MN. pp. 177-184. Dept. For. Resources, University of Minnesota, St. Paul, MN. 360 p. Tiarks, A.E., R.F. Powers, D.H. Alban, G.A. Ruark and D.S. PageDumroese. 1993. USFS Long-term soil productivity national research project: a USFS cooperative research program. In J.M. Kimble (ed.). Utilization of Soil Survey Information for Sustainable Land Use. Proc. 8th International Soil Management Workshop, May 1993, Lincoln, NE. pp. 236-241. USDA Soil Conservation Service, National Soil Survey Center. 